\title{
Foreign Language Anxiety and Its Impacts on Students' Speaking Competency
}

\author{
Kathreen B. Aguila and Ignatius Harjanto \\ Widya Mandala Catholic University
}

\begin{abstract}
Anxiety may either have negative or positive impacts on one's learning process. It is possible that anxiety may deteriorate the quality of learning process by making the learner intellectually and psychologically disturbed. In other cases, anxiety may increase students' learning motivation due to the feeling of pressure. This study aimed to investigate the factors that contribute to students' foreign language anxiety and its impacts on their speaking competency. The participants are university students taking English Conversation Class. Classroom observations were done to evaluate students' speaking performance. Other instruments were Foreign Language Class Anxiety Scale (FLCAS) questionnaire and interviews. The results showed that the students had slightly high anxiety level; and there was an invert relationship between the anxiety level and the speaking scores. Several major factors that cause anxiety among the students have been identified, and it was also seen that anxiety has its most negative impacts on students' communicative and interactive ability.
\end{abstract}

Keywords: language anxiety, factors causing foreign language anxiety, speaking competence, language learning, foreign language class anxiety scale (FLCAS)

Kecemasan mungkin memiliki dampak yang negatif atau positif pada proses pembelajaran seseorang. Ada kemungkinan bahwa kecemasan dapat menurunkan kualitas proses pembelajaran dengan membuat pelajar terganggu secara intelektual dan psikologis. Dalam situasi lain, kecemasan dapat pula meningkatkan motivasi belajar siswa karena adanya tekanan untuk melakukan yang terbaik. Studi ini bertujuan mengetahui faktor-faktor yang berkontribusi terhadap kecemasan bahasa asing siswa dan dampaknya terhadap kompetensi berbicara mereka. Partisipan studi ini adalah mahasiswa Kelas Percakapan Bahasa Inggris. Observasi kelas juga telah dilakukan untuk mengevaluasi kompetensi berbicara siswa. Instrumen lain yang digunakan berupa kuesioner Foreign Language Class Anxiety Scale (FLCAS) dan wawancara. Hasil studi menunjukkan bahwa siswa memiliki tingkat kecemasan yang sedikit tinggi; dan ada hubungan terbalik antara tingkat kecemasan dan kompetensi berbicara. Beberapa faktor utama yang menyebabkan kecemasan di kalangan mahasiswa telah diidentifikasi, dan hasil studi juga memperlihatkan bahwa seringkali kecemasan memiliki dampak negatif terhadap kompetensi komunikatif dan interaktif siswa.

Kata kunci: kecemasan bahasa, faktor penyebab kecemasan berbahasa asing, kompetensi berbicara, pembelajaran bahasa, foreign language class anxiety scale (FLCAS)

It is part of a language learning process that at some point, learners experience anxiety. E. K. Horwitz, Horwitz, \& Cope (1986, p. 128) defined foreign language anxiety as "a distinct complex of self-perceptions, beliefs, feelings, and behaviors related to classroom language learning arising from the uniqueness of the language learning process."

Correspondence concerning this article should be addressed to Kathreen B. Aguila or Ignatius Harjanto, Graduate School of English Education Department Widya Mandala Catholic University, Jl. Dinoyo 42-44 Surabaya 60265. E-mail: kraguila19@gmail.com; ig.harjanto@ gmail.com
This experience of anxiety is most likely to determine the academic performance of students inside the classroom.

In 1992, Phillips stated (cited in Shams, 2006, p. 8) that anxiety is "a complex, multi-faceted construct," and thus, anxiety may either have its debilitative or facilitative effects, depending on the students' situations. Facilitating anxiety triggers the learner to "fight" in performing the provided task; it pushes the learners to be more motivated and determined in learning. Debilitating anxiety, in contrast, impels the learner to "flee" from the given task, sti- 
mulating the learner to assume the avoidance behavior (Scovel, 1991). Debilitating anxiety has been determined to be the cause of students' reduced speaking performance (Chen \& Chang, 2004), low achievement in language learning (Budin, 2014), and other problems related to self-esteem, self-confidence and risk-taking ability, etc (Crookall \& Oxford, 1991).

This study aimed to explore the factors that contribute to student's Foreign Language Anxiety. In addition, this study also investigated the effects of Foreign Language Anxiety on students' speaking competency, which encompasses the aspect of vocabularies, grammar, communicative ability, pronunciation and intonation.

Many previous research studies have explored the anxiety-inducing factors and the learning strategies students use to cope with their anxiety (Iizuka, 2010; Hu \& Wang, 2014; Lu \& Liu, 2011; Hashemi \& Abbasi, 2013; Tanveer, 2007; Wu, 2010), while others have focused on the effects of foreign language anxiety (FLA) on students' academic performance (Azizifar, Faryadian, \& Gowhary, 2014; Budin, 2014; Chen \& Chang, 2004; Hashemi \& Abbasi, 2013; Hu \& Wang, 2014).

There are different factors that contribute to learners' foreign language anxiety, and they may either be internal or external factors. The internal factors mostly relate to the learners' sense of "self" which encompasses one's self-esteem, perceptions, beliefs, and attitudes. A negative perception towards the target language will most likely create a barrier between the language and the learner (Tanveer, 2007). The external factors, on the other hand, may involve the learning environment, teacher factors, classroom procedures and teacher-learner interactions, socio-cultural factors and other more. According to Jones (2004), previous studies have shown that language anxiety, in many cases, also has its origin in the fear of making mistakes and attracting the derision of classmates. Other factors which may cause anxiety are: (a) students' personality; (b) learner's attitude about language learning; (c) teacher's attitude about language teaching; (d) classroom procedures and teacher-learner interactions; and (e) socio-cultural factors.

It is part of teacher's responsibility to assure the quality of students' learning process, and therefore, it is also important for them to at least be aware of the presence of anxiety among the learners. In consequence, teachers can apply the appropriate means to assist and guide the students. Horwitz, et al. (1986, p. 131) state that "In general, educators have two options when dealing with anxious students: (1) they can help them learn to cope with the existing anxiety provoking situation; and (2) they can make the learning context less stressful." In addressing these concerns, there are several teaching strategies and techniques that teachers may opt to implement. It is important as well that teachers consider other factors such as the learning environment, kinds of learning activities, and learners' motivation.

To understand the relationships between FLA and students' learning process, two theoretical frameworks were used: Pekrun's Expectancy-Value Theory of Anxiety (EVTA) Model (1992) and Bandura's theory of self-efficacy (1991). Aside from these two theories, language anxiety can also be further depicted in Krashen's affective filter hypothesis and acquisition-learning hypothesis (1981).

Pekrun's EVTA model (1992) basically suggests that the control over one's achievement is assumed to depend on causal expectancies that imply appraisals of control. He claimed that the feeling of anxiety is related to the appraisals of situations as threatening or not and also to the learner's ability in dealing with the situation.

Self-efficacy asserts that anxiety depends on the individual's perception of his ability to deal positively with the potential threatening situation (Bandura, 1991). In other words, it is the belief of one's capacity to attain success in a particular situation. People with a strong sense of self-efficacy tend to view challenging problems as tasks to be overcome, and they form a stronger sense of commitment to their interests and activities.

Krashen's affective filter hypothesis (1981) believes that people acquire second languages better if they obtain comprehensible input and if their affective filters are low enough to allow the input 'in'. In his theory, an effect includes motivation, attitude, anxiety, and self-confidence. Thus, a raised affective filter can block input from reaching the Language Acquisition Device (LAD), halting the language learning process.

\section{Method}

This is a descriptive case study (Yin, 2014) which investigated how foreign language anxiety affected students' speaking competency, and also explored the different factors contributing to stu- 
dents' language anxiety. This study employed purposeful typical case sampling procedure. The target participants of this study were students of the English Conversation Class level II from a university in Surabaya, Indonesia. There were 23 students in class, with nine female and 14 male students. These students came from different faculties and attended the class every Wednesday for seven consecutive weeks, with the duration of one hour and 30 minutes per meeting.

The class observations were done on the first three out of the seven meetings, and only eleven students perfected the attendance during the span of data collection. The researcher utilized a speaking assessment rubric adopted from Authentic Assessment for English Language Learners by O'Malley and Pierce (1996) to evaluate the students' performance in the speaking activities. This rubric evaluated speaking competency in terms of five aspects: (1) vocabulary and expressions; (2) sentence structure or grammar; (3) communicative ability; (4) interaction; and (5) pronunciation and intonation. The scores from this assessment rubric were used as a basis to categorize the students into high level, middle level and low level performers. Audio-recording and note-taking were done during the classroom observations.

Another instrument that was used in this study is the Foreign Language Class Anxiety Scale (FLCAS), adopted from Horwitz, et al. (1986). The FLCAS questionnaire, used to capture the specific essence of foreign language anxiety in a classroom, was distributed to the students on the last day of class observation.

As for the self-formulated interview, six students were selected based on their speaking scores. Two students who best represent for each category of high level, middle level and low level performers, were chosen. The questions made are expected to yield responses focusing on students' perceptions and experience about foreign language anxiety, the factors causing it, and how it affects their speaking performance inside the classrooms. The interview questions were asked using English language, and the participants were also encouraged to give their responses in English. When they did not understand the question or when they could not express themselves very well in English, they switched to Indonesian. Audio-recording and notes taking were done, and the data was transcribed into English.

\section{Results}

The results from the classroom observations reflect the presence of either verbal or non-verbal manifestations of anxiety during the speaking performances. Then, the average grade for each student was computed to determine the speaking performance. As revealed by students' responses in FLCAS questionnaires, students' levels of anxiety were identified and the anxiety factors were categorized into the three related anxieties. Students' level of anxiety was further analyzed side by side with the average grades, to determine the relationship between the anxiety experienced and the speaking performance.

Out of the 23 students, only 20 students were able to respond to the FLCAS questionnaire. Horwitz (1986) confirmed that possible scores on the FLCAS ranged from 33 to 165 and the theoretical mean score is 99. The mean of all the students' scores of FLCAS in this study is 105.9, which is higher than the theoretical mean score of 99 . The minimum FLCAS score is 66 while the maximum score is 138 . It can be concluded then that this finding indicates a slightly high level of anxiety among majority of the students in ECC2.

The different situations based on the FLCAS results have been determined to be factors of the foreign language anxiety experienced by students. The number of frequency for each item in the FLCAS was tallied and the mean was computed. The responses are reflected in percentages, which refer to the number of students who agreed or disagreed with the statements. In Table 1 (see Appendix), the last column (Column 6) displayed the combinati-onal percentages of students who agreed and strong-ly agreed with the statements (or disagreed and strongly disagreed for the reverse items; item 2, 5, 8, 11, 14, 18, 22, 28, and 32). Percentages higher than $40 \%$ are considered anxietyprovoking factors to anxiety (Pramuktiyono, 2013).

As seen in Table 1 (see Appendix), the findings reveal several factors to anxiety, with the major factors falling under the category of "communication apprehension" and "fear of negative evaluation". Seventy percent of students would feel anxious when they were faced with the following situations: When they had to perform a speaking task in front of the class without having enough preparation, when being asked questions which they 
had not prepared and when they thought that others were better at English. During the interview, some students expressed that the time provided in class was not enough for them to prepare for the speaking performance. Some of the responses pertaining to their lack of preparation were as follows:

"For me, when I not prepared, not preparation for the topic. When I not preparation, in front of the class I am nervous, very nervous. And I want to finish it immediately" [Student 5]

"I feel nervous when we can't, or not yet ready, not yet finished..." [Student 1]

"I think no..there is no... uh, difficult, but. Just in ECC the difficult is like... in speaking test, is just... the teacher just give short time to prepare about the topic, it's spontantly, and we just maybe have five minutes to prepare and to go to the front to speak, I think that's so difficult" [Student 13]

"Maybe when I moving in front of the class..., and when... I'm not really ready to come in front of the class, and Ma'am Imelda say "come on, it's your time". Okay, I'm not ready, Ma'am. Like that" [Student 20]

With such responses, students seemed to find it challenging and difficult to perform a speaking task since it required them to speak instantaneously. When they were in such a situation, they got even more anxious and it would hamper their speaking performance. However, in contradiction to their responses from the interviews, there was no explicit response of students claiming to think of or feel about other students to be better speakers. On the other hand, students asserted that they felt nervous when they were called to give their answers for the exercises in the module, especially when they were uncertain of the correct answers. They would feel rattled when they were called by the teacher mostly because of not being confident of the correct answers or simply due to lack of preparation. One student mentioned:

"I feel more nervous when I can't answer the questions from the teacher" [Student 1]

According to their responses in FLCAS, other factors that also contributed to the anxiety as experienced by $65 \%$ of the students were when they worried about the consequences of failing the subject, and when they felt that others spoke English better than them. However, the interview neither revealed that the students had any worries about failing the English subject nor that they would think that others were better than them.
Some of the minor factors contributing to anxiety included situations such as classroom presentations, fear of being left behind, inability to understand the lesson, etc. It was found out as well that $50 \%$ of students still felt nervous even when they were well-prepared for the class.

As for the evaluation of students' speaking competency, this study followed the speaking assessment rubrics emphasizing the five aspects: (1) vocabulary and expressions; (2) sentence structure or grammar; (3) communicative ability; (4) interaction; and (5) pronunciation and intonation. For each aspect, the rating scale ranges from 1-4, 4 being the highest and 1 being the lowest score.

It was also found that the highest score was 85 , the lowest score was 69 , with the average mean score of 78.96 for the whole class. With the standard rating of the school, the average score of 78.96 fell on the score range of 75-79 for $\mathrm{B}+$, and it is considered to be a good performance. This indicates that in general, the students in this class showed a good performance in speaking activities, provided that the students were considered to have slightly high foreign language anxiety.

As regards to the impacts of foreign language anxiety on learners' speaking competency, Table 2 presents the summary of the evaluation results using the speaking assessment rubrics.

The findings show that the communicative and interactive abilities are mostly affected negatively by anxiety. Although students could carry on a conversation quite effectively and tried to develop the interaction in general, many others had difficulty in doing so. When they became nervous, students exhibited long pauses in between conversation, loss of words, and forgetfulness of what to say. Aside from the inability to focus because of anxiety, this was also aggravated by the limited vocabulary size that the students possessed. Below are some of students' responses:

"Maybe when I nervous in the front, I... when I prepare the topic, I can speak uh, more... speak more. But when I perform or I speak in the front, I feel blank. And my topic is uh..., maybe complicated and i... just speak spontan and not like I prepare before. It's totally different... I think because I can't focus" [Student 13]

"When I speak in front, I would be nervous. The things that I have prepared, that I want to say, I would forget" "I would forget many words. Sometimes I was already in the middle, but I don't know the continuation. Then suddenly, I'm 
Table 2

The Impacts of Foreign Language Anxiety on Students' Speaking Competence

The Impacts of Foreign Language Anxiety on Speaking Competency

\begin{tabular}{|c|c|}
\hline Dimensions of Speaking Competence & Effects on Speaking Performance \\
\hline Vocabularies and Expressions & $\begin{array}{l}\text { - Reducing words production } \\
\text { - Students didn't feel confident because of lack of vocabulary } \\
\text { - Anxiety hampered the ability to produce output smoothly } \\
\text { - Uncertainty of the correct expressions and vocabulary to use } \\
\text { - In general, students were able to use variety of words \& } \\
\text { expressions outside what was taught from the module } \\
\text { - Some words of hesitations were often said }\end{array}$ \\
\hline Grammar & $\begin{array}{l}\text { - In general, students were able to use variety of grammar structure } \\
\text { though they still commit some errors } \\
\text { - Uncertainty of the correct grammatical structure were due to lack } \\
\text { of knowledge }\end{array}$ \\
\hline Communicative Ability & $\begin{array}{l}\text { - Speaking with hesitations and pauses } \\
\text { - Jumping of ideas when speaking } \\
\text { - Disorganizing flow of thoughts } \\
\text { - Being able to maintain communication better when working with } \\
\text { partners }\end{array}$ \\
\hline Interactive Ability & $\begin{array}{l}\text { - Being able to stay on task most of the time although some } \\
\text { students can't keep up with conversation } \\
\text { - } \text { In general, students can communicate quite effectively } \\
\text { - Able to respond appropriately and keep trying to develop the } \\
\text { interaction although some others are having difficulty in this } \\
\text { aspect } \\
\text { - Exhibit long pauses in between conversation } \\
\text { - Loss of vocabulary to speak } \\
\text { - Forgetfulness about the things they want to say }\end{array}$ \\
\hline Pronunciation and Intonation & $\begin{array}{l}\text { - Clear enough and accurate pronunciation, although some would } \\
\text { commit pronunciation errors } \\
\text { - Students would ask clarifications for the correct pronunciation } \\
\text { - In general, the intonations are a bit difficult to understand } \\
\text { - Students generally have good voice quality, but some others } \\
\text { would speak in low volume } \\
\text { - Absence of stuttering or staggering voice } \\
\text { - Some students speak in English with Javanese accent }\end{array}$ \\
\hline
\end{tabular}

already ending it. So, the ideas would jump into the end because I forgot" [Student 1]

When dealing with the interactive ability, anxiety made the students speak with a lot of hesitations and pause as they carried out a conversation. The most common filler words were "uhhm" or "ahh", while others exhibited some physical gestures such as thinking gesture, swaying body movements, hand movements, etc. At the same time, students also experienced difficulty in organizing their flow of thoughts, as they responded in the interview. Despite of their preparation, they would still forget. As a result, there was a jumping of ideas, since they were not able to recall the things that they wanted to say. However, some of the participants mentioned that they seemed to feel more relaxed and were able 
to maintain communication better when they worked with partners, since they received help from each other. Stated below are some of the responses:

"I would forget many words. Sometimes I was already in the middle, but I don't know the continuation. Then suddenly, I'm already ending it. So, the ideas would jump into the end because I forgot" "I would feel nervous...But not so much because there is someone who can help" [Student 1]

When it comes to the vocabulary, results showed that most of the students experience difficulty in this aspect. Although in general, students were found to be able to use variety of words outside what was taught from the module. Few students added some expressions of praises, adjectives, and other examples, in order to make the conversation lively.

Student 3: "Oh yeah, you're very lucky because we have a discount. For single room, we have... uhm, 100 pounds. But today, we have discount, just 50 pounds, for single room. And the double room here 150 pounds, but today we have 75 pounds."

Student 21: "Uhm, fantastic! Uh... (pause) Uh, can you tell me about... the breakfast?" [Classroom Observation 3]

However, when they were overcome with anxiety, there appeared to be reduced words production. According to their responses, this was mostly caused by their lack of confidence, lack of vocabulary size, uncertainty of the correct expressions to use. Thus, anxiety hampered their ability to produce output smoothly, and some filler words were often said. Examples of their speeches with pauses and hesitations are as follows:

"Uhm, to accompany them. To live with me, where I... work. Where I work. And I... uhm... I want to... help my grandparents to... uhmm...." [Student 1, Classroom Observation 1]

"To enlarge my business and I will bring my parents to be with me. And I... uhm... I will... I will... If I have uh... more..." [Student 6, Classroom Observation 1]

"Because I graduate from product design. I will buy some land for my parents. Then, help in social work. Yeah... If I... uhm, some social projects like give free education for... for uh, students, like that." [Student 21, Classroom Observation 1] "Okay, and... and uh, main course menu? (Pause) Could I..., have um, your order?" [Student 5, Classroom Observation 2]
"Um.... (pause) umm... I, I uh... uhm... I need uh, one single room. Where is the single room?" [Student 12, Classroom Observation 3]

"Uh..., we have, we have uh... room. We have uh... single room and double room. The single room is in first, second and third floor. But in first, second, uhh (laughs). Uhh... uhh, yeah (laughs)." [Student 6, Classroom Observation 3]

Some of students' responses regarding their vocabulary size are as follows:

“Sometimes I'm scared because I can't speak what I mean very well" [Student 20]

"The difficulties is like... first, in vocabulary I think. And grammar. But the vocabulary is the main difficult, I think. Yes, because my vocabulary is limited." [Student 13]

"I don't memorize. Like, what is the English translation of the words...I lack the vocabulary" "It's more of because I lack self-confidence. The vocabulary is difficult" [Student 9]

"When I in front of class, I can't get the meaning of... my.... mind. So my factor is vocabulary" [Student 5]

As to the grammar, students in general appeared to use basic grammatical structures, and many would make frequent errors, such as the misuse of the proper prepositions, linking verbs, -ing forms, etc. Responses from the interview showed that due to the lack of knowledge in grammatical structure, students often felt uncertain of the correct grammatical structure to use, as expressed below:

"I really scared if my grammar is... I mean, I can't speak English very well, and when my grammar is... I can't speak with the grammar correctly" [Student 20]

"When I wanted to answer more, I don't know what to say. I'm not sure if the grammar is correct or not, so I don't speak" [Student 1]

"Maybe when I... feeling wrong, the structure is not right. It makes me nervous" [Student 2]

For the pronunciation, most of the students exhibited fairly clear and accurate pronunciation, although some would commit pronunciation errors. Few times, students were observed to ask for clarifications from the teacher for the correct pronunciation of words. In some cases, students would commit mistakes in the pronouncing the words using the correct stress. In terms of intonations, most students were a bit difficult to understand. This may be due to the low volume of voice when the students speak, although few students seemed to have good voice quality. Some students appeared to 
possess Javanese accent in speaking English, and it was also observed that there was absence of stuttering or staggering voice even if there was presence of anxiety.

\section{Discussion}

Generally, students are highly anxious when attending the English class. Based on the FLCAS responses, the major factors of anxiety in this study were identified. Despite this condition, their evaluation and average grades reflect that their speaking performances in the class were considered to be good, following the school's standards. However, the results of the study reveal that anxiety did have mostly negative impacts on students' speaking competency.

According to their responses in FLCAS, $70 \%$ of the students would be in panic when asked to perform speaking activities without having enough preparation. Padmadewi (1998), in her study, confirmed that students would feel anxious in speaking class because of the pressure from speaking tasks which required them to present spontaneously within a limited time. Similarly, another prominent anxiety-inducing situation inside the classroom was when students were asked questions which they had not prepared in advance, as revealed in the FLCAS percentage of $70 \%$ students. In addition, responses from the interview show that students would feel anxious to do speaking performance because of the inadequate time for preparation.

Another identified situation causing anxiety to $70 \%$ students is when they thought that other students were better in English. Then, sixty five percent of students would also worry about the consequences of failing their English class. According to Azizifar, et al. (2014), factors such as lack of confidence, lack of preparation and fear of failing the class are the primary causes of students' anxiety. However, the results from the interviews did not reveal any information whether they did experience these two kinds of situations. Perhaps, the nature of the interview was such that the responses of the students were directed in other specific aspects other than this area of concern.

As expressed in the interview, most students asserted that they considered the speaking performance to be a challenging and anxiety-producing situ- ation in the classroom. This difficulty was caused by of their inability to produce words instantaneously and due to the lack of vocabulary size. Some students are afraid of speaking because of lack of grammatical knowledge. As a consequence, many students did not feel confident about themselves speaking in English. According to Horwitz, et al. (1986), those students who have low self-confidence tends to have high anxiety, and unsure of their own capabilities, afraid to be humiliated, etc. This kind of situation also supports the study done by Worde (2003) claiming that students would feel anxious in speaking class due to lack of vocabulary and lack of grammatical knowledge. Thus, these factors hinder their speaking competency. However, this situation seemed to give the idea of anxiety being produced because of the lack of grammatical knowledge, instead of the other way around. Thus, it can be said that anxiety aggravates one's speaking performance, in addition to one's lack of grammatical knowledge.

The results also suggested that anxiety had a negative impact on students' cognition, which then affected their interactive and communicative ability. Some of the students stated that due to anxiety, they found it difficult to focus in class. Others would experience forgetfulness and some inability to carry out the conversation smoothly. When they experienced anxiety, many others would forget the things that they had prepared. In their research, Chen \& Chang (2004) claim that when students experience anxiety, there will be reduced word production when they perform in front of the class, sometimes causing a mental block. This condition also supports Krashen's Affective Filter Hypothesis (1981) that whenever a strong emotion such as anxiety is present, the brain filter will be closed causing a mental block or forgetfulness.

One student admitted that he was afraid of being laughed at by his classmates when he would commit mispronunciations, and that is why he tried to be always careful when speaking in front. Liu (2007) stated that one of the prominent factors of anxiety is the fear of making mistakes and being laughed at.

In a study by Azizifar, et al. (2014), they concluded that there was a negative correlation between anxiety and learners' oral performance. They asserted that the higher the students' level of anxiety, the lower their oral performance scores are. This pattern is evident in the individual speaking performance, even though the class performs quite well in general. 
Table 3

Summary of Student's Speaking Performance and FLCAS Scores

\begin{tabular}{lccr}
\hline \multicolumn{1}{c}{ Category } & Student & Speaking Score & FLCAS Score \\
\hline High level performers & Student 13 & 85 & 81 \\
& Student 5 & 84.5 & 66 \\
Middle level performers & Student 2 & 78.5 & 101 \\
& Student 20 & 79 & 106 \\
Low level performers & Student 1 & 69 & 122 \\
& Student 9 & 73.5 & 115 \\
\hline
\end{tabular}

Focusing on the students' performance, observed students who got high score in their classroom speaking performance actually showed a low FLCAS score. While the middle level performers obtained a moderately high FLCAS, those who performed poorly in speaking activity obtained a higher FLCAS score. This indicates that language anxiety has a negative impact on student's performance in the class. The differences can be seen in the performances of some students, as presented in Table 3.

Meanwhile, the results from the speaking evaluation reveal that the aspect of speaking competency which was most affected negatively by anxiety was the interactive ability, next to the communicative ability. The class generally was able to carry out the conversation and sustain interaction by responding appropriately, although many of the students would fail to do so. Most of them speak with some hesitations such as "ahhm" or "uhh", and it sometimes interferes with communication. Some students also would often pause in between the dialogues or the speech because of various reasons such as lack of preparation, forgetfulness, lack of vocabulary, lack of grammatical knowledge, inability to focus, etc. In some cases, students still feel anxious despite of having ample preparation for the class. Tanveer (2007) asserted that despite of the effort that language learners put into memorizing and rehearsing their oral presentations, they still feel stressed and would forget what has been prepared.

With all the findings presented, the effects of anxiety towards the students were mostly negative. Aside from their own awareness of the lack of vocabulary and grammatical knowledge, the feeling of anxiety would aggravate the tense situations inside the classroom. As a result, their speaking performance was low. And since anxiety is a multifaceted phenomenon, there are several aspects of language learning that may be affected, aside from one's speaking skills. The other aspects may include self-confidence, behaviors in performance, motivation, and thought organization. On the other hand, anxiety also was found out to have positive impacts on some students, as mentioned in the prior discussion. Thus, even though there are sources of anxiety that are commonly experienced by students, it is a rather unique and personal experience for each learner, in accordance to one's situations and conditions.

\section{Limitations and Further Research Opportunities}

Since this study is intended mainly to investigate the impact of foreign language anxiety (FLA) to students' speaking competence, there are many other aspects in language learning that are not included. Thus, the focus of the topic itself presents many limitations of the present study. Since anxiety is one of the factors that affect language learning in general, it is most likely that anxiety also impacts the other linguistic skills aside from speaking (listening, reading and writing skills).

The present study also did not include the roles of the teachers in the language learning process. Since teachers play a key role in learning, it is also important to know the strategies or techniques that will help alleviate the students' anxiety. In relation to this, the present study also excluded the possible learners' strategies in coping up with their anxiety. Dwelling deeper into this aspect might be insightful 
not only to the learners themselves, but also to the teachers because those are the possible ways by which students can improve their classroom performance.

Based on the results of the study, it can be suggested that the management of anxiety lies heavily on the teacher. Considering the different factors inducing anxiety on students, teachers can pay attention to some of the learning aspects that can be remedied. Some situations that can possibly help alleviating students' anxiety include providing more time to prepare for speaking performance within the reasonable time limit, being attentive to learner's conditions, learning needs and motivation level, providing a friendly and accommodating learning environments, encouraging more natural and collaborative works.

For any future research with the same topic, there are several suggestions that can be made. The scope of the research may be extended to exploring the relationship of anxiety with the different language skills, which will most likely provide a more holistic view of how foreign language anxiety affects language learning process. When it comes to the participants, future studies can be conducted in a similar English class but with different level of students, since it might yield to different responses towards language anxiety. Other aspects that can be looked up to are the teacher's role in the anxiety management or alleviation, teaching strategies and techniques that can be implemented, students' coping strategies, and many more.

\section{Conclusion}

It is believed that anxiety has its either facilitative or debilitative effects on one's learning process. This study reveals that the students themselves were aware that they often feel anxious in the class, and at the same time they are also aware of some of the negative impacts of language anxiety on their speaking performance. The speaking scores reflect that language anxiety has an inverse relationship with the students' performance inside the classroom. However, the general performance of the class in ECC2 is considered to be good $(\mathrm{B}+)$ in spite of the experience of slightly high foreign language anxiety.

The results showed that the factors were mostly subjective in nature, pertaining to self-confidence about their own ability of using English to speak. They were aware of the need to practice the language constantly, or to apply other means in order to make improvements in their English skills. However, they tended to limit themselves with the opportunities that they had. For instance, they only speak English inside the classroom, and even then, they do not speak in English all the time.

By nature, speaking performances are challenging since it requires people to speak instantaneously with fluency, considering as well the flow of ideas to be presented. Thus, it takes good language skills and knowledge of the language with a certain degree of mastery in order to perform well. Most of the students are not able to achieve this competency because of various reasons, such as lack of vocabulary, knowledge in grammar, lack of self-confidence, etc. However, these challenges can be overcome by constant practice and exposure to the target language.

\section{References}

Azizifar, A., Faryadian, E., \& Gowhary, H. (2014). The effect of anxiety on Iranian EFL learners' speaking skill. International Research Journal of Applied and Basic Sciences, 8(10), 1747-1754.

Bandura, A. (1991). Self-efficacy conception of anxiety. In R. Schwarzer \& R. A. Wicklund (Eds.), Anxiety and self-focused attention (pp. 89-110). London: Harwood Academic Publishers.

Budin, L. H. (2014). Investigating the relationship between English language anxiety and the achievement of school based oral English test among Malaysian form four students. International Journal of Learning, Teaching and Educational Research, 2(1), 67-79.

Chen, T. Y., \& Chang, G. B. Y. (2004). The relationship between foreign language anxiety and learning difficulties. Foreign Language Annals, 37(2), 279-287.

Crookall, D., \& Oxford, R. (1991). Dealing with anxiety: Some practical activities for language learners and teacher trainees. In E. K. Horwitz \& D. J. Young (Eds.). (1991). Language anxiety: From theory and research to classroom implications (pp.141-150). Englewood Cliffs, NJ: Prentice-Hall.

Hashemi, M., \& Abbasi, M. (2013). The role of the teacher in alleviating anxiety in language classes. International Research Journal of Applied and Basic Sciences, 4(3), 640-646.

Horwitz, E. K., Horwitz, M. B. \& Cope, J. A. (1986). 
Foreign language classroom anxiety. The Modern Language Journal, 70(2), 125-132.

$\mathrm{Hu}$, L., \& Wang, N. (2014). Anxiety in foreign language learning. Paper presented at the International Conference on Global Economy, Commerce and Service Science, 1, 122-124. Retrieved from http://www.atlantis-press.com/php/pub.php ?publication $=$ gecss $-14 \&$ frame $=\mathrm{http} \% 3 \mathrm{~A} / / \mathrm{www} . \mathrm{a}$ tlantis-press.com/php/paper-details.php $\% 3$ Fid $\% 3$ D10950

Jones, J. F. (2004). A cultural context for language anxiety. English Australia Journal, 21(2), 30-39.

Krashen, S. (1981). Second language acquisition and second language learning. Oxford: Pergamon Press.

Liu, M. (2007). Anxiety in oral English classrooms: A case study in China. Indonesian Journal of English Language Teaching, 3(1), 119-137.

Lu, Z., \& Liu, M. (2011). Foreign language anxiety and strategy use: A study with Chinese undergraduate EFL learners. Journal of Language Teaching and Research, 2(6), 1298-1305.

O'Malley, M. J., \& Pierce, L. V. (1996). Authentic assessment for English language learners: Practical approaches for teachers. New York: Addison-Wesley Publishing.

Padmadewi, N. (1998). Student's anxiety in speaking class and ways of minimizing it. Jurnal Ilmu Pendidikan, 5, 60-67.

Pekrun, R. (1992). Expectancy-value theory of anxiety: Overview and implications. In D. For-gays \& T. Sosnowski (Eds.), Anxiety: Recent developments in cognitive, psychophysiological, and health research (pp. 23-39). Washington, DC: Hemisphere.

Pramuktiyono, A. (2013). An investigation of students' foreign language anxiety and its relationships with their beliefs about language learning at English education study program of UNIROW Tuban, East Java, Indonesia. English Education Study Program in Universitas PGRI Ronggolawe (UNIROW) Tuban, East Java, Indonesia.

Scovel, T. (1991). The effect of affect on foreign language learning: A review of the anxiety research, in E. K. Horwitz \& D. J. Young (Eds.) Language anxiety: From theory and research to classroom implications (pp.15-24). Englewood Cliffs, NJ: Prentice Hall.

Shams. (2006). The use of computerized pronunciation practice in the reduction of foreign language classroom anxiety (Unpublished doctoral dissertation). Florida State University, Tallahassee, Florida.

Tanveer, M. (2007). Investigation of the factors that cause language anxiety for ESL/EFL learners in learning speaking skills and the influence it casts on communication in the target language. Academia, 64, 1-92.

Worde, R. V. (2003). Students' perspectives on foreign language anxiety. Inquiry, 8(1), 1-15.

Wu, K.-h. (2010).The relationship between language learners' anxiety and learning strategy in the CLT classrooms. International Education Studies, 3(1), 174-191.

Yin, R. K. (2014). Case study research: Design and methods (5th ed.). Los Angeles: SAGE Publications, Inc. 


\section{Appendix}

Table 1

Frequency of Students' Responses (in \%) and Mean Score per FLCAS item

\begin{tabular}{|c|c|c|c|c|c|c|c|}
\hline SITUATIONS & $M$ & 1 & 2 & 3 & 4 & 5 & 6 \\
\hline $\begin{array}{l}\text { 1. I never feel quite sure of myself when I am speaking English in my } \\
\text { class. }\end{array}$ & 3.5 & 5 & 40 & 55 & 0 & 0 & $45^{*}$ \\
\hline 2. I don't worry about making mistakes in the English class. & 2.8 & 0 & 45 & 35 & 15 & 5 & 20 \\
\hline $\begin{array}{l}\text { 3. I tremble when I know that I'm going to be called on in the English } \\
\text { class. }\end{array}$ & 3.1 & 0 & 45 & 25 & 25 & 5 & $45^{*}$ \\
\hline $\begin{array}{l}\text { 4. It frightens me when I don't understand what the teacher is saying in } \\
\text { English. }\end{array}$ & 3.4 & 0 & 50 & 40 & 10 & 0 & $50^{*}$ \\
\hline 5. It wouldn't bother me at all to take more foreign language classes. & 2.8 & 0 & 30 & 60 & 10 & 0 & 10 \\
\hline $\begin{array}{l}\text { 6. During my English class, I find myself thinking about things that have } \\
\text { nothing to do with the course. }\end{array}$ & 3.4 & 5 & 30 & 65 & 0 & 0 & 35 \\
\hline 7. I keep thinking that the other students are better at English than I am. & 3.85 & 20 & 50 & 25 & 5 & 0 & $70^{*}$ \\
\hline 8. I am usually at ease during English tests in my class. & 2.95 & 0 & 25 & 55 & 20 & 0 & 20 \\
\hline $\begin{array}{l}\text { 9. I start to panic when I have to speak without preparation in the English } \\
\text { class. }\end{array}$ & 3.5 & 25 & 45 & 10 & 20 & 0 & $70^{*}$ \\
\hline 10. I worry about the consequences of failing my English class. & 3.65 & 10 & 55 & 25 & 10 & 0 & $65^{*}$ \\
\hline 11. I don't understand why some people get so upset over English classes. & 2.85 & 0 & 35 & 50 & 10 & 5 & 15 \\
\hline 12. In the English class, I can get so nervous I forget things I know. & 3.75 & 20 & 45 & 25 & 10 & 0 & $65^{*}$ \\
\hline 13. It embarrasses me to volunteer answers in my English class. & 3.05 & 0 & 30 & 45 & 25 & 0 & 30 \\
\hline 14. I would not be nervous speaking English with native speakers. & 3.1 & 0 & 35 & 25 & 35 & 5 & $40^{*}$ \\
\hline 15. I get upset when I don't understand what the teacher is correcting. & 3.5 & 10 & 40 & 40 & 10 & 0 & $50^{*}$ \\
\hline 16. Even if I am well prepared for the English class, I feel anxious about it. & 3.2 & 5 & 45 & 20 & 25 & 5 & $50^{*}$ \\
\hline 17. I often feel like not going to my English class. & 2.8 & 5 & 25 & 25 & 35 & 10 & 30 \\
\hline 18. I feel confident when I speak English in class. & 2.8 & 0 & 30 & 60 & 10 & 0 & 10 \\
\hline $\begin{array}{l}\text { 19. I am afraid that my English teacher is ready to correct every mistake I } \\
\text { make. }\end{array}$ & 3.55 & 0 & 35 & 30 & 30 & 5 & 35 \\
\hline $\begin{array}{l}\text { 20. I can feel my heart pounding when I'm going to be called on in the } \\
\text { English class. }\end{array}$ & 3.3 & 5 & 50 & 15 & 30 & 0 & $55^{*}$ \\
\hline 21. The more I study for an English test, the more confused I get. & 3.15 & 10 & 30 & 25 & 35 & 0 & $40^{*}$ \\
\hline 22. I don't feel pressure to prepare very well for the English class. & 2.2 & 25 & 45 & 15 & 15 & 0 & 15 \\
\hline 23. I always feel that the other student speak English better than I do. & 3.75 & 15 & 50 & 30 & 5 & 0 & $65^{*}$ \\
\hline
\end{tabular}




\begin{tabular}{|c|c|c|c|c|c|c|c|}
\hline SITUATIONS & $M$ & $\mathbf{1}$ & 2 & 3 & 4 & 5 & 6 \\
\hline 24. I feel very anxious about speaking English in front of other students. & 3.2 & 15 & 20 & 35 & 30 & 0 & 35 \\
\hline 25. The English class moves so quickly I worry about getting left behind. & 3.4 & 20 & 35 & 20 & 25 & 0 & $55^{*}$ \\
\hline $\begin{array}{l}\text { 26. I feel more tense and nervous in my English class than in my other } \\
\text { classes. }\end{array}$ & 3.2 & 10 & 30 & 30 & 30 & 0 & $40 *$ \\
\hline 27. I get nervous and confused when I am speaking English in class. & 3.15 & 5 & 35 & 35 & 20 & 5 & $40 *$ \\
\hline 28. When I'm on my way to the English class, I feel very sure and relaxed. & 2.45 & 0 & 55 & 45 & 0 & 0 & 0 \\
\hline $\begin{array}{l}\text { 29. I get nervous when I don't understand every word the English teacher } \\
\text { says. }\end{array}$ & 3.35 & 5 & 40 & 40 & 15 & 0 & $45^{*}$ \\
\hline $\begin{array}{l}\text { 30. I feel overwhelmed by the number of rules I have to learn to speak } \\
\text { English. }\end{array}$ & 3.2 & 0 & 30 & 60 & 10 & 0 & 30 \\
\hline 31. I am afraid that the other students will laugh at me when I speak English. & 3.3 & 10 & 30 & 40 & 20 & 0 & $40 *$ \\
\hline 32. I would probably feel comfortable around native speakers of English. & 3.2 & 0 & 5 & 70 & 25 & 0 & 25 \\
\hline $\begin{array}{l}\text { 33. I get nervous when the English teacher asks questions which I haven't } \\
\text { prepared in advance. }\end{array}$ & 3.9 & 20 & 50 & 30 & 0 & 0 & $70^{*}$ \\
\hline
\end{tabular}

Note. $\quad M=$ mean, $1=$ strongly agree, $2=$ agree, $3=$ neither agree nor disagree, $4=$ disagree, $5=$ strongly disagree, $6=$ both strongly agree and agree (or disagree and strongly disagree for the reverse items). *refers to the combinational percentage of both "strongly agree" and "agree" (or disagree and strongly disagree for the reverse items) that is more than $40 \%$. 